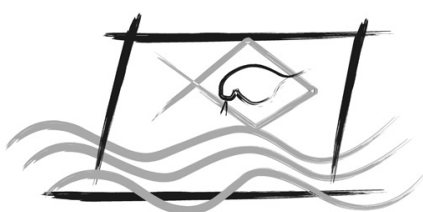

ECOTOX - BRASIL

\title{
Acute toxicity from a prototype equipment of water separation through solar distillation on Daphnia magna Straus, 1820
}

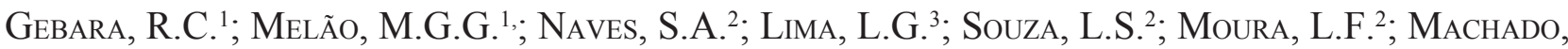 \\ A.M.R. ${ }^{3} \&$ PRINTES, L.B. ${ }^{4}$ \\ 1 Department of Hydrobiology, Federal University of São Carlos, Rod. Washington Luis Km 235, Zip Code: 13565-905, \\ São Carlos-SP, Brazil. \\ 2 Department of Chemical Engineering, Federal University of São Carlos. \\ 3 Department of Waste Management, Federal University of São Carlos. \\ 4 Department of Support to Environmental Education, Federal University of São Carlos.
}

(Received September 02, 2016; Accept August 01, 2017)

\begin{abstract}
The use of sustainable forms of energy should be encouraged, considering the damages that usual sources of energy can cause to our planet, which are often irreversible for decades or centuries. Despite the sun being the main source of energy on Earth, in tropical countries like Brazil, this kind of energy could be better exploited. The present work aims to evaluate the toxicity of purified water and a solution of $\mathrm{CuSO}_{4}$, after decontamination in a prototype equipment of solar distillation of wastewater (due to separation of condensed water from non-volatile substances), in order to test the efficiency of the equipment. Thus, acute toxicity tests were performed with Daphnia magna. The $\mathrm{EC}_{50}-48 \mathrm{~h}$ values (the median concentration of a substance that causes effect to fifty percent of organisms) for deionized water and solution of $1 \mathrm{mg} \mathrm{L}^{-1}$ of $\mathrm{CuSO}_{4}$, both after distillation, were $19.61 \%$ and $17.08 \%$, respectively. Results indicates that the final samples from the equipment were toxic to D. magna, and therefore, with a potential risk for the freshwater biota. Based on that, it is recommended improvements in the equipment structure, to reduce toxicity, since it occurred probably by contamination of the structures of the equipment itself.
\end{abstract}

Keywords: Daphnia magna; Ecotoxicology; risk assessment; solar distillation; wastewater treatment.

\section{INTRODUCTION}

Currently, waste production and management is a universal problem. According to Shutkin (2001), the United States produces about 113 trillion kilograms of general waste per year. The number of laboratories of academic institutions, private industries and pharmaceutical companies that generate large amount of residual substances is of great concern. At Universities, waste is produced in small amounts, but they have different sources and levels of toxicity (Nascimento \& Tenuta-Filho, 2010), because of the different kinds of researches in progress, and, in most cases, are discarded in the environment, and may cause damage to natural ecosystems.

In Brazilian academic institutions, this problem can be even worse, because, usually, there are few discussions and institutional policies about the destination of wastewater from research and educational laboratories. In many cases, waste is stocked inappropriately and finally discarded in the sanitary drain or garbage (Jardim, 1998; Gerbase et al., 2005; Imbroisi et al., 2006). In Brazil, just about $67 \%$ of the sanitary sewer is treated before being dumped in rivers, lakes and reservoirs (Brazil, 2013).

Copper sulfate $\left(\mathrm{CuSO}_{4}\right)$ was used in present work as a simulation of wastewater. $\mathrm{CuSO}_{4}$ has many uses: phytoplankton control (Padovesi-Fonseca \& Philomeno, 2004), fungicide (Mirlean et al., 2005), reference toxicant (Struewing et al., 2015), and as analytical reagent for chemical and biomedical analysis (Pistorius et al., 1996; Tsu et al., 2004).

In the other hand, studies have shown that copper is toxic to several organisms, such as: fishes (Hernández et al., 2006), 
cladocerans (Rodgher et al., 2009), cnidarians (Markich \& Camilleri, 1997) and algae (Franklin et al., 2000; Rocha et al., 2016). According to CONAMA, National Environment Council (Brazil, 2005), the maximum allowed concentration of dissolved copper in waters categorized as 'class 1', is 0.009 $\mathrm{mg} \mathrm{L}^{-1}$. Thus, it is important that the discarded of copper be appropriate and new ways of decontamination of this substance be studied.

In this context, it is important to develop methodologies for treating effluents from academic laboratories (or others) and at the same time monitor the possible impact of these effluents on aquatic biota.

Ecotoxicology offers important tools for evaluating the level of toxicity of discarded substances and predict what they might cause in natural environments. Chemical analysis are useful for identifying substances, but are not able to show the toxic effects of these substance on ecosystems (Magalhães \& Ferrão-Filho, 2008) and to assess potential environmental risks. For this purpose, ecotoxicological evaluations are extremely necessary (Costa et al., 2008).Cladocerans of Daphnidae family, e.g. Daphnia magna (Straus 1820), are included in national and international protocols for testing toxicants and environmental samples and have been extensively used in Ecotoxicological studies (ABNT, 2009).

It is well known that the study of new technologies that can provide more efficient ways of decontaminating different types of wastewaters is very relevant. According to SWERA (Solar and Wind Energy Resource Assessment) project, that studied solar energy resources from 1995 to 2005, Brazil has superior values of flux of global solar radiation than in countries of the European Union (Martins et al., 2007). The states of Bahia (BA) and Santa Catarina (SC), have the maximum and minimum values of global daily radiation of the country, which corresponds to $6.5 \mathrm{kWh} \mathrm{m}^{-2}$ and $4.25 \mathrm{kWh}$ $\mathrm{m}^{-2}$, respectively (Echer et al., 2006).

Based on this, it was created a unique prototype of solar distiller, which is, in theory, capable to decontaminate nonvolatile substances of the water, using just solar radiation as energy for the whole process, in order to take advantage of the large solar radiation that occurs in Brazil. The present investigation was carried out to prevent pollution and suggest improvements on the equipment. Therefore, this paper aims to experimentally investigate the prototype equipment's final product, analyzing possible toxicity of the distilled samples, to evaluate the efficiency of the whole process. It was expected that the final products would not be toxic, since the substance tested must not condensate with the water at the experimental temperatures reached.

\section{MATERIAL AND METHODS}

\section{Operation of the equipment.}

The system of distillation presented in this paper is a low cost innovation product (Figure 1), that was design to separate volatile substances from non-volatile ones. The equipment is a combination of passive and active solar distillation and it was thought to be used in countryside communities.

The passive process consists of glass plate (Figure 1, A) that works as a condenser and has an inclination of $30^{\circ}$, oriented northwards to get the maximum solar light incidence in an entire day. The active portion consists of two solar plates (Figure 1, D) with small tubes filled with glycerin that works as heating medium.

After the entire process, the distilled water, separated from the non-volatile substances, flows into a channel (Figure 1, B) and is collected in a reservoir. The wastewater product, with these non-volatile substances can be removed from distiller by opening a tap (Figure 1, C). The capacity of the equipment is around 20 liters.

\section{Organisms}

\section{Algal cultures}

The algae Pseudokirchneriella subcapitata was cultured in L.C. Oligo medium (AFNOR, 1980), pH 6.0-7.0, previously

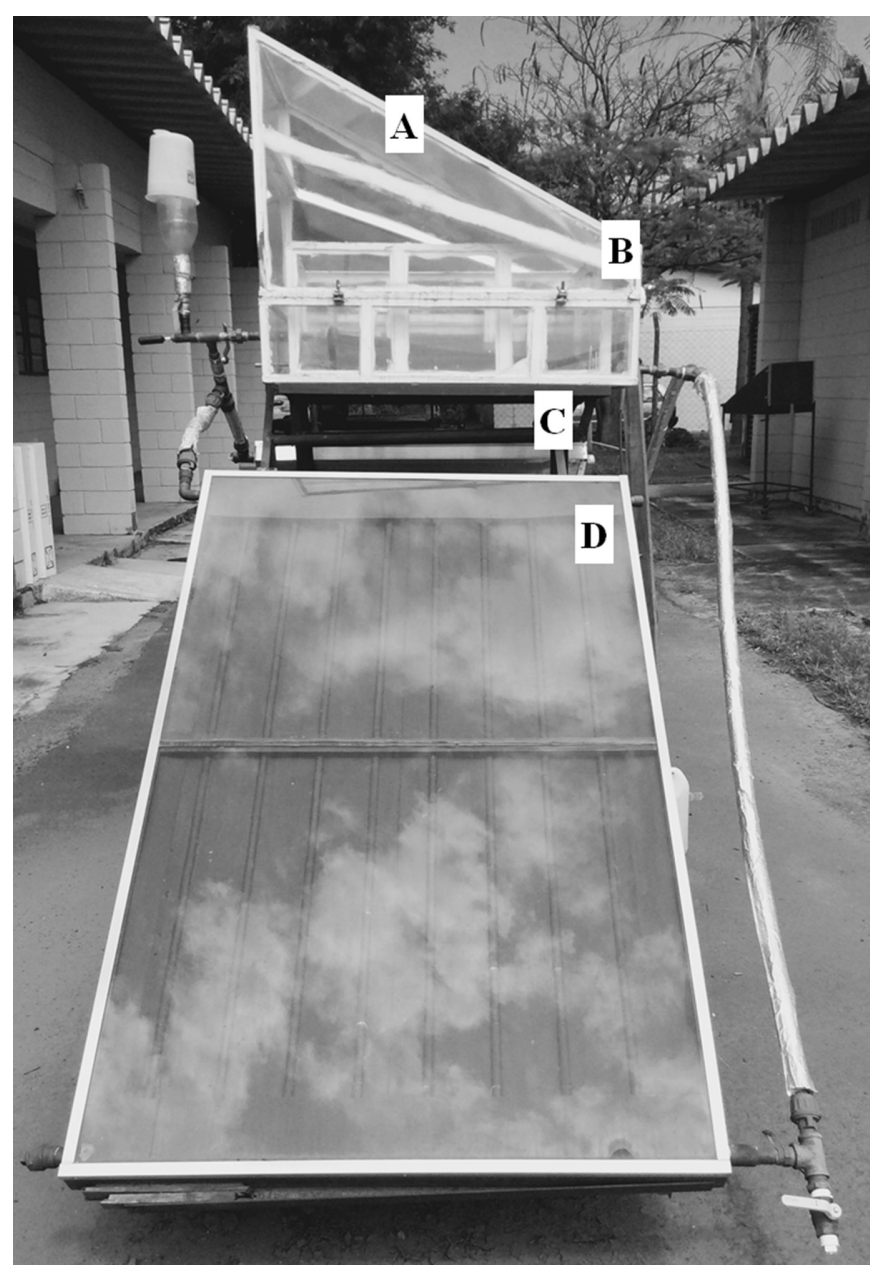

Figure 1. Representation of the prototype of solar distiller. Main structures: glass plate (A), condensate collection (B), wastewater output (C) and solar panel (D) 
autoclaved at $121^{\circ} \mathrm{C}$ and $1 \mathrm{~atm}$ for $20 \mathrm{~min}$. The medium was inoculated with the algae in exponential growth phase, in aseptic conditions. Cultures were maintained at $25 \pm 2^{\circ} \mathrm{C}$, with a photoperiod of $12 \mathrm{~h} / 12 \mathrm{~h}$ dark/light. For food preparation, the algae were centrifuged (Eppendorf 5702, Germany) at $2000 \mathrm{rpm}$ for 10 minutes at $4{ }^{\circ} \mathrm{C}$, and then the cells were resuspended in reconstituted hard water. After that, the number of cells was estimated by using a Neubauer chamber, in a microscope (Leica DMLS, Germany) with a magnification of 400 times.

\section{Zooplankton}

Daphnia magna individuals were obtained from stock cultures maintained in the Experimental Aquaculture Station of the Department of Hydrobiology $\left(21^{\circ} 58^{\prime} 55^{\prime \prime} \mathrm{S}\right.$ and $47^{\circ} 52^{\prime} 35^{\prime}$ 'W), at the Federal University of São Carlos, Brazil.

The cladocerans were kept in an incubator cabinet (Nova Ética B.O.D. 411/D, Brazil) under static conditions at $25 \pm 1{ }^{\circ} \mathrm{C}$ with photoperiod of $12 \mathrm{~h} / 12 \mathrm{~h}$; dark/light. The microcrustaceans were fed with suspensions of green algae $P$. subcapitata at a concentration of $3 \times 10^{5}$ cells $\mathrm{mL}^{-1}$ and they had also a complementary diet, based in suspension of dried baker's yeast.

Each D. magna clonal culture were started with juveniles $(\leq$ $24 \mathrm{~h}$-old), from third to fifth brood, isolated from parthenogenetic mothers and consisted of twenty adult organisms in a 2000 $\mathrm{mL}$ beaker, filled with $1500 \mathrm{~mL}$ of reconstituted hard water (ASTM, 2002) around 220-225 $\mathrm{mg} \mathrm{CaCO}_{3} \mathrm{~L}^{-1}$, under $\mathrm{pH}$ 7.68.0, that was full renewed three times a week. The health and sensitivity of organisms was assured by tests with the reference toxicant sodium chloride $(\mathrm{NaCl})$. All parameters for the cultures followed national standards (ABNT, 2009).

\section{Acute toxicity tests}

The acute tests with D. magna consisted in the exposure of 20 neonates $(<24$ h-old) per treatment $(\mathrm{N}=4)$, therefore with 5 neonates in each replicate, in dilutions using reconstituted hard water, in the following sample concentrations: 100; $50 ; 25 ; 12.5$ and $6.25 \%$. The experiments were conducted in polystyrene flasks containing $15 \mathrm{~mL}$ of test solution, kept in the dark and with no food supply.

After $24 \mathrm{~h}$ and $48 \mathrm{~h}$, the immobile organisms were counted with the aid of a stereomicroscope (Leica MZ6, Germany). The EC50 (effective concentration, that causes immobility to $50 \%$ of test organisms) values were estimated by the Trimmed Spearman-Karber method (Hamilton et al., 1977). The $\mathrm{pH}$ and conductivity measurements were taken at the beginning and the end of the experiments. Tests were validated when immobility in the control, with same number of replicates of other test solutions, did not exceed 10\% (Abnt, 2009) and temperature during the tests do not deviate by more than $3^{\circ} \mathrm{C}$.

We analyzed 3 samples, in the follow experiments:

Test 1: consisted of distilled water purified by reverse osmosis, used in the zooplankton cultures. This water was tested after passing through the process of solar distillation in the prototype equipment (Figure 1); in order to observe any toxicity related to the equipment that could be generated during the process, regardless the initial solution used in it. Pure culture water was used for the control group.

Test 2: the same purified water cited earlier, tested after process of solar distillation, this time in an equipment made $100 \%$ with glass, which was washed with hydrochloric acid $(10 \%)$, and thus free of contamination, aiming to prove the non-contamination of the water used as the initial solution in the Test 1 .

Test 3 , solution of copper sulfate, in a concentration of $1 \mathrm{mg}$ $\mathrm{L}^{-1}$, tested after the same distillation process in the equipment of Test 1 , aiming to simulate the possible decontamination of laboratory waste.

\section{Metal determination}

The total copper was determinate in the final distillate sample of Test 3, which had an initial test solution of $1 \mathrm{mg}$ $\mathrm{L}^{-1}$ (nominal concentration) of $\mathrm{CuSO}_{4}$. The total copper concentration was determinate by colorimetric method using spectrophotometry.

\section{RESULTS AND DISCUSSION}

All the experiments, including sensitivity and definitive tests were validated, since immobility in control groups did not exceed $10 \%$ (Figure 2), the temperature in chambers, during the tests, did not deviate more than $1{ }^{\circ} \mathrm{C}$ and $\mathrm{pH}$ (Table 1) did not vary more than 0.7 in the control groups.

Sensitivity tests performed corroborated the viability and health of the test organisms. Mean values of $\mathrm{EC}_{50}-24$ $\mathrm{h}$ and $48 \mathrm{~h}$ - were 6.41 and $5.93 \mathrm{~g} \mathrm{~L}^{-1}$ of $\mathrm{NaCl}$, with standard deviation of 0.53 and 0.19 , and coefficient of variation values of $8 \%$ and $3 \%$, respectively. These results were similar to the $\mathrm{LC}_{50}-48 \mathrm{~h}$ values found in literature: $5.55 \mathrm{~g} \mathrm{~L}^{-1}$ (Santos et al., 2007); $4.77 \mathrm{~g} \mathrm{~L}^{-1}$ (Mount et al., 1997) and $6.03 \mathrm{~g} \mathrm{~L}^{-1}$ (Cowgill \& Milazzo, 1991).

According to Figure 2, the percentage of immobile organisms indicate that the samples on Tests 1 and 3 were toxic, after experimental process of decontamination. At Test 1 , using purified water, after distillation, the $\mathrm{EC}_{50}-48 \mathrm{~h}$ value was $19.61 \%$ (Table 2), which, is classified as very toxic (Bulich, 1982). Thus, this wastewater was not suitable for discharging in natural environments. Since the water used in the process was free of contamination, we can infer that some material that is part of the structure of the equipment was toxic, and thus the toxicity was transferred to the water.

After the collection of samples and the end of toxicity tests, it was observed that a part of the distiller that connects two hoses, which carry the distillate, was connected by a copper structure. This could be the reason for the toxicity, since copper can be released from pipes, becoming a source of metal in water 
Table 1. Variables of ecotoxicology tests, measured at the beginning and end of experiments.

\begin{tabular}{|c|c|c|c|c|c|}
\hline \multirow{2}{*}{ Test } & \multirow{2}{*}{$\begin{array}{l}\text { Sample } \\
(\%)\end{array}$} & \multicolumn{2}{|c|}{$\mathrm{pH}$} & \multicolumn{2}{|c|}{$\begin{array}{l}\text { Conductivity } \\
\left(\mu \mathrm{S} \mathrm{cm}^{-1}\right)\end{array}$} \\
\hline & & initial & final & initial & final \\
\hline \multirow{6}{*}{1} & Control & 7.6 & 8.3 & 756.8 & 861.1 \\
\hline & 6.25 & 7.4 & 8.3 & 713.7 & 813.6 \\
\hline & 12.5 & 7.4 & 8.2 & 663.7 & 762.4 \\
\hline & 25 & 7.4 & 8.1 & 583.6 & 670.3 \\
\hline & 50 & 7.1 & 7.9 & 389.5 & 478.9 \\
\hline & 100 & 6.0 & 7.3 & 3.858 & 38.12 \\
\hline \multirow{6}{*}{2} & Control & 7.6 & 8.3 & 701.6 & 705.3 \\
\hline & 6.25 & 7.2 & 8.3 & 655.4 & 662.7 \\
\hline & 12.5 & 7.2 & 8.4 & 621.9 & 615.3 \\
\hline & 25 & 7.2 & 8.2 & 542.1 & 543.1 \\
\hline & 50 & 7.1 & 7.9 & 364.4 & 383.6 \\
\hline & 100 & 7.0 & 7.3 & 29.78 & 51.40 \\
\hline \multirow{6}{*}{3} & Control & 7.9 & 8.35 & 765 & 750 \\
\hline & 6.25 & 7.8 & 8.38 & 693 & 659 \\
\hline & 12.5 & 7.8 & 8.30 & 682 & 455 \\
\hline & 25 & 7.79 & 8.30 & 614 & 401 \\
\hline & 50 & 7.7 & 8.02 & 435 & 328 \\
\hline & 100 & 5.65 & 7.22 & 2.9 & 48.1 \\
\hline
\end{tabular}

(Rushing \& Edwards, 2004). Nevertheless, this hypothesis does not exclude combined toxic effects related to other components of the equipment, such as painting and glue. Further evaluations need to be carried out to test these possibilities.

Since some organic compounds are easily volatile, they cannot be removed from the water by distillation process. A study of Fernández-Alba et al. (2002) demonstrated, for example, that some antifouling biocides added to painting, which are used in hulls of watercraft, were to toxic to $D$. magna and Vibrio fischeri. Thus, the painting used in the distiller's fabrication could be the cause of the toxicity pointed in Test 1 , due to a possible contamination.

Test 2 was conducted in a glass container free of contaminants. The purified water was placed in the glass container, and after few days of solar radiation, the water was distilled and concentrated in a glass beaker inside the container. The $\mathrm{EC}_{50}-48 \mathrm{~h}$ value of this concentrated could not be calculated (Table 2), therefore, the result was non-toxic.

This latter result proved that: (I) the water used in the laboratory of Plankton was adequate for the tests; (II) the process of distillation in a clean inert container did not cause toxicity in the samples; (III) and the ecotoxicological tests were effective in demonstrating non detected toxicity in the purified water.

Test 3 was performed with a solution of $1 \mathrm{mg} \mathrm{L}^{-1}$ of copper sulfate, after distillation, simulating the decontamination of wastewater. $\mathrm{EC}_{50}-48 \mathrm{~h}$ of Test 3 was $17.08 \%$ (Table 2), a little higher than Test 1, and thus, the sample was classified as very toxic (Bulich, 1982).

Chemical determination showed a concentration of 0.27 $\mathrm{mg} \mathrm{L}^{-1}$ of total copper in the final distillate (Test 3). Metal trace in the samples could not be explained by the initial test solution of copper, since this substance does not evaporate during the distillation process, once $\mathrm{CuSO}_{4}$ boiling point is $650^{\circ} \mathrm{C}$ (Weast, 1987).

The $\mathrm{EC}_{50}-48 \mathrm{~h}$ of $D$. magna for copper is only $6.5 \mu \mathrm{g}$ $\mathrm{L}^{-1}$ (Dave, 1984), classified as an extremely toxic substance (Zucker, 1985). This test indicated that the water was not suitable for dump in natural environments. According to Brazil (2005), resolution 357/2005, the allowed maximum value for dissolved copper in water is $0.009 \mathrm{mg} \mathrm{L}^{-1}$, for freshwaters classified as 'class 1', which aimed to protect the aquatic communities.

Other values founded in literature for $\mathrm{CuSO}_{4}$ to $D$. similis is $0.01 \mathrm{mg} \mathrm{L}^{-1}\left(\mathrm{EC}_{50}-48 \mathrm{~h}\right.$ ) (Tavares et al., 2014) and $0.0826 \mathrm{mg} \mathrm{L}^{-1}\left(\mathrm{LC}_{50}-48 \mathrm{~h}\right)$ for D. magna (Guilhermino et al., 2000), which means that this genera is highly sensitive to this compound. Thus, the toxicity could be explained by the copper structures in the distiller, that possible leached the metal to the water, as mentioned in Test 1.

In addition to acute toxicity tests, chronic exposures need also to be performed in future studies, as in the work of Magdeburg et al. (2012). They analyzed survival and reproductive endpoints in D. magna, to test the efficiency of new steps for water decontamination in a wastewater treatment plant.

Other studies have also used cladocerans as test organisms, for testing: (1) the toxicity of pharmaceutical active compounds, detected chemically in wastewater treatment plants in Korea, by the acute and chronic toxicity tests. The authors concluded that the pharmaceutics indicated a low biological risk in that study area (Han et al., 2006); (2) the toxicity of textile wastewater of a factory in Turkey, after processes of ozonation and coagulation, in order to decolorize and detoxify the water. The wastewater was toxic to D. magna (immobility as endpoint) even in the dilution of $150 \%$ (Selcuk, 2005).

In countryside communities, this prototype equipment could also be applied to obtain and reuse water for irrigation, for example. It is well known that wastewater irrigation can cause risks for human health, such as infections by helminths and organic or inorganic contaminants (Qadir et al., 2010).

The purpose of the present work was to test a low cost equipment of water decontamination, which only demands solar energy to function, and could be used for professional and domestic purposes, being accessible for a large number of people, especially those in developing countries. This equipment has a high potential for use, once same parts of it could be replaced for others materials, since we showed that the process of distillation itself did not cause toxicity, demonstrated through the experiment in the equipment made of $100 \%$ of glass, in which the water had been condensate with no toxicity at the end of the process.. We believe that 

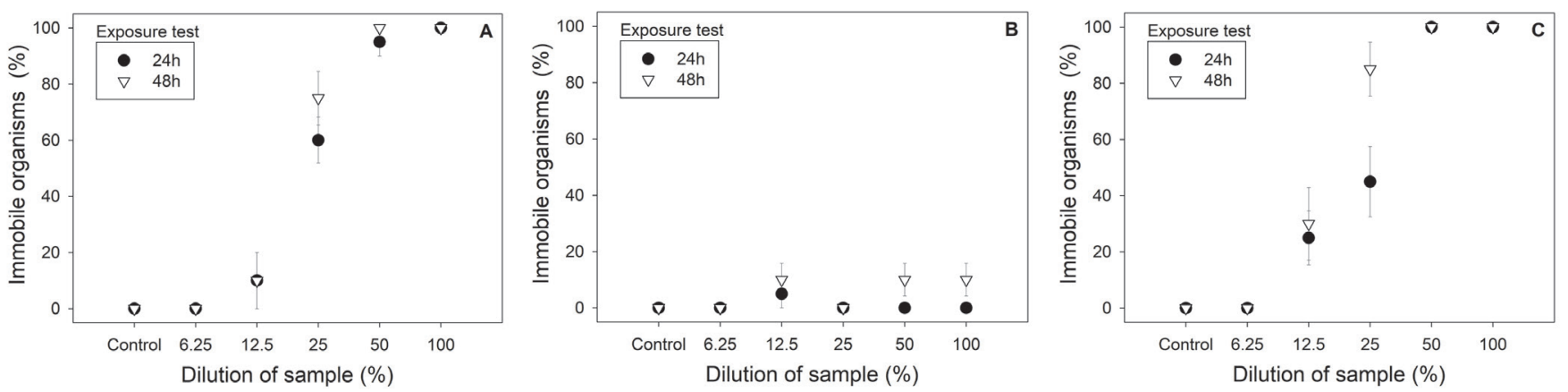

Figure 2. Detailed data of immobility for D. magna, for tests 1, 2 and 3, represented respectively, in A, B and C.

Table 2. Values of $\mathrm{EC}_{50}$ for D. magna and their respective level of toxicity, according to (Bulich, 1982).

Test $\quad \mathrm{EC}_{50}(\%) \quad \mathrm{CI}^{*}(95 \%) \quad$ Exposure $\quad$ Result

\begin{tabular}{lcccc}
\hline & 23.33 & $19.24-28.27$ & $24 \mathrm{~h}$ & \\
& 19.61 & $16.66-23.09$ & $48 \mathrm{~h}$ & Very toxic \\
& $\mathrm{NC}^{* *}$ & - & $24 \mathrm{~h}$ & \\
& $\mathrm{NC}^{* *}$ & - & $48 \mathrm{~h}$ & Non-toxic \\
& 21.76 & $17.74-26.70$ & $24 \mathrm{~h}$ & \\
& 17.08 & $14.04-20.76$ & $48 \mathrm{~h}$ & Very toxic \\
\hline
\end{tabular}

$\mathrm{CI}^{*}$ : confidence interval.

$\mathrm{NC}^{* *}$ : non-calculable.

this was the possible route of contamination in the prototype equipment of solar distillation, with contamination through the others structures of the equipment itself (that are not made of glass), evidenced by the concentrations of copper measured in the final condensed water.

\section{CONCLUSIONS}

The toxicity presented in the tested samples was caused by some material retained in the distiller, probably allocated after the process of condensation. Since the principle of solar distillation is that volatile substances evaporate, condense and then separate from the non-volatile ones, if there was a contamination before the condensation system, it would be decontaminated a posteriori. We conclude that the equipment is not ready for use yet, since its final remaining caused toxicity to the tested organism, D. magna. Since chemical analysis pointed copper in final samples of distillate, we suggest the replacement of the copper structure that carry the distillate, between two hoses, for a not toxic material, e.g. glass, polycarbonate or polystyrene. The long-term implications of this study will impact the design of the next distillers and in the selection of materials that will be used in their fabrication. After the improvements in the equipment, new ecotoxicology studies are needed before it can be used in large scale.

\section{ACKNOWLEDGEMENTS}

This work was supported by the National Program of University Extension, Ministry of Education (ProEXT/MEC - Brazil). The authors thank Federal University of São Carlos by the infrastructure provided.

\section{REFERENCES}

ABNT (Brazilian National Standards Organization). 2009. Acute Toxicity - Test with Daphnia spp (Cladocera, Crustacea). NBR 12713, Rio de Janeiro, RJ.

AFNOR (Association Française de Normalisation). 1980. Norme experimentale. T90-304. Essais deseaux Determination de I'nhibition de Scenedesmus subspicatus par une substance, Paris.

BRAZIL (Ministry of the Environment. National Environmental Council - CONAMA). 2005. Resolution n. 357/2005, March 17th, Brasília, DF.

BRAZIL (Ministry of Cities. National Secretary of Environmental Sanitation). 2013. Diagnóstico dos serviços de água e esgoto, Brasília, DF.

BULICH, A.A. 1982. A Practical and Reliable Method for Monitoring the Toxicity of Aquatic Samples. Process Biochem.: 45-47.

COSTA, C.R., OLIVI, P., BOTTA, C.M.R. \& ESPINDOLA, E.L.G. 2008. A toxicidade em ambientes aquáticos: discussão e métodos de avaliação. Quim. Nova, 31(7): 1820-1830, http://dx.doi. org/10.1590/S0100-40422008000700038

COWGILL, U.M. \& MILAZZO, D.P. 1991. Demographic effects of salinity, water hardness and carbonate alkalinity on Daphnia magna and Ceriodaphnia dubia. Arch. Hydrobiol., 122: 35-56.

DAVE, G. 1984. Effects of copper on growth, reproduction, survival and haemoglobin in Daphnia magna. Comp. Biochem. Physiol., 78C(2): 439-443, http://dx.doi.org/10.1016/07428413(84)90112-9

ECHER, M.P.S., MARTINS, F.R. \& PEREIRA, E.B. 2006. The significance of the cloud cover data and its variability Methodology to data acquisition. Rev. Bras. Ens. Fis., 28(3): 341-352, http://dx.doi.org/10.1590/S1806-11172006000300011

FERNÁNDEZ-ALBA, A.R., HERNANDO, M.D., PIEDRA, L. \& CHISTI, Y. 2002. Toxicity evaluation of single and mixed antifouling biocides measured with acute toxicity bioassays. Anal. Chim. Acta, 456(2): 303-312, http://dx.doi.org/10.1016/ S0003-2670(02)00037-5

FRANKLIN, N.M., STAUBER, J.L., MARKICH, S.J. \& LIM, R.P. 2000. $\mathrm{pH}$-dependent toxicity of copper and uranium to a tropical freshwater alga (Chlorella sp.). Aquat. Toxicol., 48(2-3): 275289, http://dx.doi.org/10.1016/S0166-445X(99)00042-9

GERBASE, A.E., COELHO, F.S., MACHADO, P.F.L. \& 
FERREIRA, V.F. 2005. Gerenciamento de resíduos químicos em instituições de ensino e pesquisa. Quim. Nova, 28(1), http:// dx.doi.org/10.1590/S0100-40422005000100001

GUILHERMINO, L., DIAMANTINO, T., SILVA, M.C. \& SOARES, A.M. 2000. Acute toxicity test with Daphnia magna: an alternative to mammals in the prescreening of chemical toxicity? Ecotoxicol. Environ. Saf., 46(3): 357-62, http://dx.doi. org/10.1006/eesa.2000.1916

HAMILTON, M.A., RUSSO, R.C. \& THURTON, R.V. 1977. Trimed Spearman-Karber method for estimating median lethal concentrations in toxicity bioassays. Environ. Sci. Technol., 11(7): 714-719, http://dx.doi.org/10.1021/es60130a004

HAN, G.H., HUR, H.G. \& KIM, S.D. 2006. Ecotoxicological Risk of Pharmaceuticals from Wastewater Treatment Plants in Korea: Occurrence and Toxicity to Daphnia Magna. Environ. Toxicol. Chem., 25(1): 265-271, http://dx.doi.org/10.1897/05-193r.1

HERNÁNDEZ, P.P., MORENO, V., OLIVARI, F.A. \& ALLENDE, M.L. 2006. Sub-lethal concentrations of waterborne copper are toxic to lateral line neuromasts in zebrafish (Danio rerio). Hear. Res., 213(1-2): 1-10, https://doi.org/10.1016/j. heares.2005.10.015

IMBROISI, D., GUARITÁ-SANTOS, A.J.M., BARBOSA, S.S., SHINTAKU, S.D.F., MONTEIRO, H.J., PONCE, G.A.E., FURTADO, J.G., TINOCO, C.J., MELLO, D.C. \& MACHADO, P.F.L. 2006. Gestão de resíduos químicos em universidades: Universidade de Brasília em foco. Quim. Nova, 29(2): 404-409, http://dx.doi.org/10.1590/s0100-40422006000200037

JARDIM, W.F. 1998. Gerenciamento de resíduos químicos em laboratórios de ensino e pesquisa. Quim. Nova, 21(5): 671-673, http://dx.doi.org/10.1590/S0100-40422005000100001

MAGALHÃES, D.P. \& FERRÃO-FILHO, A.S. 2008. A Ecotoxicologia como ferramenta no biomonitoramento de ecossistemas aquáticos. Oecol. Bras., 12(3): 355-381.

MAGDEBURG, A., STALTER, D. \& OEHLMANN, J. 2012. Whole effluent toxicity assessment at a wastewater treatment plant upgraded with a full-scale post-ozonation using aquatic key species. Chemosphere, 88(8): 1008-1014, http://dx.doi. org/10.1016/j.chemosphere.2012.04.017

MARKICH, S.J. \& CAMILLERI, M. 1997. Investigation of metal toxicity to tropical biota: Recommendations for revision of the Australian water quality guidelines. Supervising Scientist Report 127, Canberra. Available in: http://www.environment. gov.au/system/files/resources/8a512fc2-93ad-4950-885c8e23797140de/files/ssr127-web.pdf.

MARTINS, F.R., PEREIRA, E.B., GUARNIERI, R.A., SILVA, S.A.B., YAMASHITA, C.S. \& CHAGAS, R.C. 2007. Mapeamento dos recursos de energia solar no Brasil, utilizando modelos de transferência radiativa Brasil-SR. I Congresso Brasileiro de Energia Solar, Fortaleza - Brazil.

MIRLEAN, N., ROISENBERG, A. \& CHIES, J.O. 2005. Copperbased fungicide contamination and metal distribution in Brazilian grape products. Bull. Environ. Contam. Toxicol., 75(5): 968974, http://dx.doi.org/10.1007/s00128-005-0844-3

MOUNT, D.R., GULLEY, D.D., HOCKETT, J.R., GARRISON, T.D. \& EVANS, J.M. 1997. Statistical models to predict the toxicity of major ions to Ceriodaphnia dubia, Daphnia magna and Pimephales promelas (fathead minnows). Environ. Toxicol. Chem., 16(10): 2009-2019, http://dx.doi.org/10.1002/ etc. 5620161005

NASCIMENTO, E.D.S. \& TENUTA-FILHO, A. 2010. Chemical waste risk reduction and environmental impact generated by laboratory activities in research and teaching institutions. Braz.
J. Pharm. Sci., 46(2): 187-198, http://dx.doi.org/10.1590/s198482502010000200004

PADOVESI-FONSECA, C. \& PHILOMENO, M.G. 2004. Effects of algicide (Copper Sulfate) application on short-term fluctuations of phytoplankton in Lake Paranoá, Central Brazil. Braz. J. Biol., 64(4): 819-826, http://dx.doi.org/10.1590/S151969842004000500011

PISTORIUS, L.R., FUNK, M., PATTINSON, R.C. \& HOWARTH, G.R. 1996. Screening for anemia in pregnancy with copper sulfate densitometry. Int. J. Gynaecol. Obstet., 52(1): 33-36, http://dx.doi.org/10.1016/0020-7292(95)02559-6.

QADIR, M., WICHELNS, D., RASCHID-SALLY, L., MCCORNICK, P.G., DRECHSEL, P., BAHRI, A. \& MINHAS, P.S. 2010. The challenges of wastewater irrigation in developing countries. Agric. Water. Manag., 97(4): 561-568, http://dx.doi. org/10.1016/j.agwat.2008.11.004

ROCHA, G.S., LOMBARDI, A.T. \& MELAO MDA, G. 2016. Influence of phosphorus on copper toxicity to Selenastrum gracile (Reinsch) Korshikov. Ecotoxicol. Environ. Saf., 128: 30-35, http://dx.doi.org/10.1016/j.ecoenv.2016.02.007

RODGHER, S., LOMBARDI, A.T. \& GAMA MELAO MDA, G. 2009. Evaluation onto life cycle parameters of Ceriodaphnia silvestrii submitted to 36 days dietary copper exposure. Ecotoxicol. Environ. Saf., 72(6): 1748-1753, http://dx.doi. org/10.1016/j.ecoenv.2009.03.009

RUSHING, J.C. \& EDWARDS, M. 2004. The role of temperature gradients in residential copper pipe corrosion. Corr. Scie., 46(8): 1883-1894, http://dx.doi.org/10.1016/j.corsci.2003.11.001

SANTOS, M.A.P.F., VICENSOTTI, J. \& MONTEIRO, R.T.R. 2007. Sensitivity of Four Test Organisms (Chironomus xanthus, Daphnia magna, Hydra attenuata and Pseudokirchneriella subcapitata) to NaCl: an Alternative Reference Toxicant. J. Braz. Soc. Ecotoxicol., 2(3): 229-236, http://dx.doi.org/10.5132/ jbse.2007.03.004

SELCUK, H. 2005. Decolorization and detoxification of textile wastewater by ozonation and coagulation processes. Dyes Pigm., 64(3): 217-222, http://dx.doi.org/10.1016/j.dyepig.2004.03.020

SHUTKIN, W.A. 2001. The Environmental Consequences of Civic Decline. In: SHUTKIN, W. A. (Ed.). The Land That Could Be: Environmentalism and Democracy in the Twenty-First Century. 1.Cambridge, Massachusetts: MIT Press, pp. 45-88.

STRUEWING, K.A., LAZORCHAK, J.M., WEAVER, P.C., JOHNSON, B.R., FUNK, D.H. \& BUCHWALTER, D.B. 2015. Part 2: Sensitivity comparisons of the mayfly Centroptilum triangulifer to Ceriodaphnia dubia and Daphnia magna using standard reference toxicants; $\mathrm{NaCl}, \mathrm{KCl}$ and $\mathrm{CuSO} 4$. Chemosphere, 139: 597-603, http://dx.doi.org/10.1016/j. chemosphere.2014.04.096

TAVARES, K.P., CALOTO-OLIVEIRA, Á., VICENTINI, D.S., MELEGARI, S.P., MATIAS, W.G., BARBOSA, S. \& KUMMROW, F. 2014. Acute toxicity of copper and chromium oxide nanoparticles to Daphnia similis. Ecotoxicol. Environ. Contam., 9(1): 43-50, http://dx.doi.org/10.5132/eec.2014.01.006

TSU, V.D., LANGER, A. \& ALDRICH, T. 2004. Postpartum hemorrhage in developing countries: is the public health community using the right tools? Int. J. Gynaecol. Obstet., 85 Suppl 1: S42-51, http://dx.doi.org/10.1016/j.ijgo.2004.02.009

WEAST, R.C. 1987. Handbook of Chemistry and Physics. 68th. CRC Press Inc., Boca Raton, FL. p. B-90p.

ZUCKER, E. 1985. Hazard Evaluation Division, Standard Evaluation on Procedure: Acute toxicity test for freshwater fish. EPA Procedure: Acute toxicity test for freshwater fish. EPA 540/9/85006, Washington, DC. 